\title{
STUDYING LIVER REGENERATION BY MEANS OF MOLECULAR BIOLOGY: HOW FAR WE ARE IN INTERPRETING THE FINDINGS?
}

\author{
David Rychtrmoc ${ }^{1,2}$, Antonín Libra ${ }^{2}$,Martin Bunček ${ }^{2}$,Tomáš Garnol ${ }^{1}$,Zuzana Červinkováa ${ }^{1}$ \\ Charles University in Prague, Faculty of Medicine in Hradec Králové, Czech Republic: Department of Physiology; \\ GENERI BIOTECH Ltd., Hradec Králové, Czech Republic ${ }^{2}$
}

\begin{abstract}
Summary: Liver regeneration in mammals is a unique phenomenon attracting scientific interest for decades. It is a valuable model for basic biology research of cell cycle control as well as for clinically oriented studies of wide and heterogeneous group of liver diseases. This article provides a concise review of current knowledge about the liver regeneration, focusing mainly on rat partial hepatectomy model. The three main recognized phases of the regenerative response are described. The article also summarizes history of molecular biology approaches to the topic and finally comments on obstacles in interpreting the data obtained from large scale microarray-based gene expression analyses.
\end{abstract}

Key words: Liver Regeneration; Hepatectomy; Gene Expression; Microarray, Hepatocytes; Rat

\section{Introduction}

The liver regeneration attracts scientific attention for decades as a unique phenomenon in mammalian physiology. The interest does not decline in recent years. It rather grows as its relevancy to clinical situations and discovery potential for basic research are well recognised.

New methods employed in this field yield important and useful knowledge which in turn shapes design of further studies. The literature dealing with liver regeneration is replete and arises from various scientific branches including but not limited to physiology, genomics, radiology and imaging disciplines, tissue engineering and liver surgery and transplantation fields. The aim of this article is to provide a brief review of current understanding of the mechanisms of liver regeneration, list molecular biology approaches employed in this field and to bring a discussion of challenges arising when interpreting the results of recent microarray gene expression analyses.

\section{On the normal architecture and function of the liver}

The liver is a vital organ performing plenty of essential body functions. It synthesizes and secretes plasma proteins and majority of clotting factors; maintains blood glucose and ammonia levels critical for central nervous system function. Creation of bile and urea and many more roles in intermediate metabolism and elimination of both endogenous and exogenous substances make liver the main detoxifying organ of the body.
Concerning the structure the liver is an organ with a complex architecture, with several cell populations taking part. The parenchymal cells - hepatocytes build up sixty per cent of the total cell count and eighty per cent of the overall organ volume. The remaining twenty per cent is shared by lining cells of liver sinusoids and several types of immune system cells, Ito cells and epithelial cells of intrahepatic bile ducts. Kupffer cells and dendritic cells belong among the resident immune system cells, while various subpopulations of lymphocytes rank among the migrating ones. Ito cells, called also stellate (or fat-storing) can produce several paracrine factors and thus play a regulatory role in extracellular matrix remodelling and eventual development of liver fibrosis $(28,37)$.

Basically, the liver parenchyma is organised into hexagonal lobules each having a centrally located hepatic vein, terminal branch of systemic venous vasculature draining blood into the inferior vena cava. Each structural lobule is surrounded by usually six peripherally located portal spaces, containing mainly triads of following structures: terminal branch of portal vein, terminal branch of hepatic artery and interlobular bile duct. Besides these lymphatic vessels, nerves and small amount of interstitial connective tissue can be found in portal spaces (Fig. 1). Only $3 \%$ of liver volume is constituted by extracellular matrix (ECM), making the liver highly cell dense organ.

Despite its small proportion the ECM can importantly influence the signal transduction by binding or release of regulatory substances either in active or inactive form. ECM compounds can even perform cleavage of the humoral factors to increase or limit their function (54). 

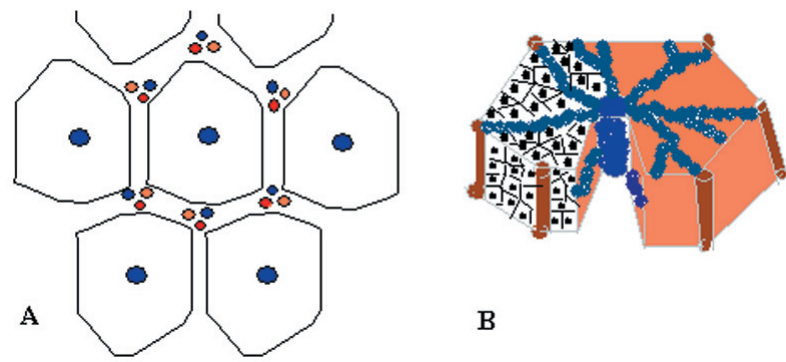

Fig. 1: Simplified representation of liver parenchyma microarchitecture. A) View of several neighbouring structural lobules, each having a centrally located vein. Triads of structures stand for portal triads in each corner of the approximately hexagonal lobule. B) Closer look at the single lobule structure. Portal triads are again simply represented in its corners. We see also several sinusoids, spanning from the terminal branches of portal vein to the central vein. Individual hepatocytes are shown on the left, while the right part of the picture implies the spatial organisation of the lobule. For details see text.

Functional division of the liver parenchyma follows different principles, main factor being the quality of blood supply to the hepatocytes. From this point of view portal triads are central structures to the functional hepatic acini. Each acinus has three zones numbered I to III from the centre to the periphery with oxygen and nutrients levels decreasing with the distance from the portal triad $(48,55)$. The differences in the characteristics of supplied blood are responsible for so called functional heterogeneity of hepatocytes among the zones of acini, impacting the scope of metabolic activities and susceptibility or resistance to oxygen or nutrient deprivation or chemical intoxication.

\section{Importance and description of the liver regenerative capacity}

Referring to liver regenerative capacity would be incomplete without mentioning the ancient Greek myth of Prometheus, who brought people the secret of fire from the divine seat mount Olympus and was punished by chaining to a rock. Every day an eagle arrived to batten on his liver, which amazingly regrew its volume again.

The liver is a central organ in above mentioned inevitable functions and at the same time it is due to its localisation first exposed to antigenic and toxic substances ingested by an organism. These enter the liver via its functional blood supply by portal vein. Portal vein collects blood from all other azygous abdominal organs, thus presenting vast entrance gateway of exogenous substances (and endogenous catabolites as well) into the internal environment of an organism. It is hypothesized that the unique regenerative capacity of the liver is an adaptation to this enormous load with an intention to enable survival of a being, which for instance tried a previously unknown feed. The liver regenera- tion feature is seen in all vertebrates from fish to humans (38).

Liver functions can not be omitted during the regeneration. Hepatocytes do not dedifferentiate during the regeneration and are capable of readily bearing increased functional demands after loss of part of the organ volume $(5,13)$. It is truly amazing that the regenerating liver despite the reduced mass serve the rest of the body by all of its homeostatic functions (38).

The minimal volume of the liver remnant capable of such functioning and simultaneous recovery from an insult has been subject to research and both in animals and humans survivable 90 per cent liver resections were reported $(16,49)$. In such a large scale hepatectomies additional measures are employed to increase the survival rate. These include high energy diets or portal vein arterialization in experimental and clinical settings $(9,40,42)$.

The liver regeneration after partial hepatectomy is not only a biological model for study of tissue homeostasis but it may also bring better insight into the regeneration of the donor liver remnant in the living donor liver transplantation. Surgeons could then provide safer care for donors who are preoperatively healthy volunteers and harm to them should be avoided or minimised (24). Donor complications are nowadays reported with varying methodology, which leads to largely different results among the transplantation centres (1). Other clinically relevant settings are liver resections due to tumour metastases or liver injury. Developers of artificial liver support devices also seek knowledge about the mechanisms of regeneration in effort to increase their efficiency $(5,43)$.

It is worth emphasizing that unless specifically prevented, the liver volume restoration is accomplished by proliferation of mature parenchymal cells - hepatocytes, unlike wound repair seen in skin or small intestine $(38,56)$. A record number of 12 sequential hepatectomies performed in rats without failure of the regenerative potential of the liver was reported (51). Overturf and colleagues (1997) have shown even more striking results with adult mice hepatocytes. Increase in telomerase activity may contribute to this almost endless capacity of hepatocytes to divide in vivo. Moderate (up to twofold) increase in telomerase activity was found in regenerating rat hepatocytes, but there is a detectable telomerase activity in quiescent rodent livers which is not the case in humans (17). A study in pig model, which better fits human telomerase biology with no activity in quiescent livers, revealed even fivefold increase in telomerase activity after two thirds partial hepatectomy (63).

\section{In vivo models of liver regeneration}

The need of in vivo models of liver regeneration is emphasized by complexity of the process. Significance of the interactions among all liver cell populations is nowadays undoubted and the action of circulating modulators of extrahepatic origin can not be simulated in vitro. Moreover 


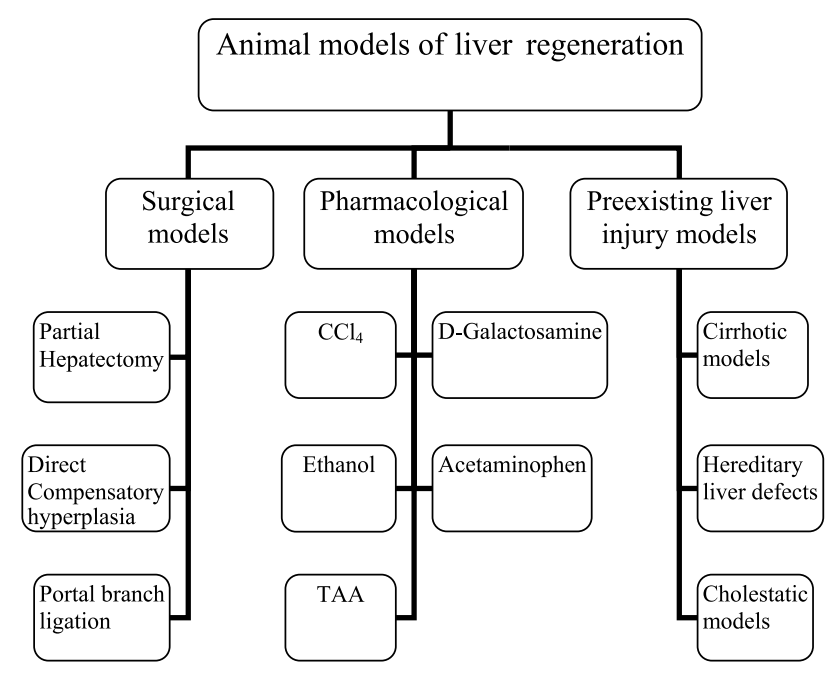

Fig. 2: Animal models of liver regeneration. Adapted with kind permission from Ref. 43. TAA = thioacetamide; $\mathrm{CCl}_{4}$ $=$ tetrachlormethane

the regulation by body functional demands is only possible in the whole organism (43). Studies in humans present ethical obstacles and also the heterogeneity of conditions leading to liver injury in clinical settings complicates evaluation of such studies (44).

Animal in vivo studies are a reasonable compromise in terms of availability, affordability, reproducibility and standardised conducting and evaluation. But of course evidence exist about differences in physiology of regeneration among smaller and higher animals and situation in humans (43). The already established animal models are summarised in Fig. 2.

The time frame of liver regeneration depends on the kind of organ damage and its severity and extent. Rats or mice are the most frequently used model organisms because the liver regeneration is especially rapid in small rodents. In both species two thirds partial hepatectomy first introduced by Higgins and Anderson in 1931 (19) is the prevalent intervention. The anatomical differences necessitate adjustment of surgical procedure for the actual species, but both techniques are widely spread. While rat model gives more reproducible results, mice are valuable for the possible use of genetically engineered strains (13). The full organ size restoration is reported within 5 to 10 days in most of the rodent studies.

In humans reported times necessary for liver regeneration vary greatly among the articles. It is of course due to the different insults studied and varied methods used for measuring the organ size. But there is even no consensus about the completeness of the response. While Michalopoulos (2007) states that normal liver weight is re-established in 8-15 days in humans, followed by a slow lobular reorganization taking place for several weeks (62), Court et al., (2002) states, that under normal circumstances, the liver regeneration in humans is initiated within 3 days and by 6 months the recovery of original mass is complete. Transplant clinician Manzarbeitia (2002) in clinical setting of living donor liver transplantations witnesses almost complete restoration of both the donors' and recipients' livers in 6-8 weeks, with most of the recovery occurring in the first two weeks. Older report by Jansen (1990) found out maximal $75 \pm 2 \%$ size recovery after a post partial hepatectomy follow-up period of 50 days. Taken together it is not simple to determine the time needed for ultimate recovery in humans and the comprehensive discussion of this issue is above the frame of this article.

\section{Overview of liver regeneration principles}

Response of the liver to a damaging insult which is not immediately lethal to the organism is commonly called "regeneration" although it does not fulfil criteria for doing so. The principle is different from what is seen in amphibians regrowing lost limbs. It is not a new creation of lost tissue in its original localisation. In fact, the remaining mature cells undergo replication, and thus enlargement of unaffected organ remnant underlies the volume recovery of the liver. Therefore the phenomenon should be named compensatory hyperplasia $(12,56)$. Nevertheless the term liver regeneration is already well established and is commonly used even in scholarly literature. That is why we keep the term also in this article.

The liver regeneration occurs after a variety of different insults including the mechanic tissue loss (injury, resection) or necrosis of some portion of the liver cells without reduction in organ volume (leading to functional deficiency) caused e.g. by ischemia, acute or chronic intoxication eventually by infection (typically viral hepatitis).

It is generally accepted, that the liver regeneration process after the loss of functional mass consists of three fundamental phases: a) initiation or priming, progression of the quiescent hepatocytes to repeated division, b) proliferative phase, restoring the liver tissue to its volume before an insult and c) termination of growth and balancing the resultant size of the liver to just comply with functional demands of the organism (14).

\section{Priming phase}

Hepatocytes the most numerous liver cells are long lived elements which rarely divide. Their replication rate is one in twenty thousand (50). Under normal conditions hepatocytes are irresponsive to growth stimuli. This changes amazingly after an appropriate triggering event, partial hepatectomy being among the most efficient ones.

Other triggering events are necrosis after blunt injury, metabolic stress imposed e.g. by toxins, or any phenomenon leading to disruption of intercellular contacts $(10,25$, 43) or digestion of the extracellular matrix (31).

This change from quiescent to cycling state is called priming and is generally ascribed to cytokine-dependent sig- 
nalling pathways action in short time after an insult. It is concluded that the triggering factors must be in place faster than de novo proteosynthesis could occur and that they are substances already present in the body. One of the suggested early initiators is lipopolysaccharide (LPS), produced by the gut flora and released from the intestines as a consequence of deteriorated intestinal barrier due to surgical stress. LPS reaches liver with the portal blood and can readily influence its cells. The LPS activates the non-parenchymal cells (including Kupffer cells and stellate cells) and increases their production of tumour necrosis factor alpha (TNF $\alpha$ ) and interleukin 6 (IL-6) (56). Another substances acting as rapidly as LPS are activated complement compound $\mathrm{C} 3 \mathrm{a}$ and $\mathrm{C} 5 \mathrm{a}$, showing that the response is not isolated to the liver itself, but that the circulating factors take part as well $(35,53)$.

Cytokine signals including TNF $\alpha$ and IL- 6 cause transcription factors NFKB, STAT3, AP-1 and CEBP $\beta$ to bind DNA rapidly by means of their posttranslational modifications $(6,12)$. Subsequently, in 20 to 30 minutes after the $\mathrm{PH}$, derepressed transcription factors increase expression of so called immediate early genes. These include the protooncogenes c-fos, c-jun, c-myc and c-met, the latter being the HGF receptor (52).

Cytokine mediated pathway is responsible for $\mathrm{G} 0 / \mathrm{G} 1$ transition, after which the action of growth factors is inevitable. Complete hepatic mitogens recognised in vivo and also in primary hepatocyte cultures are HGF, TGF $\alpha$, and EGF. These allow cells to overcome the G1 restriction point and continue towards mitosis (32).

Extrahepatic body organs also have a role to play in reaction to liver injury. Cooperative priming signals come from the pancreas (insulin), duodenum or salivary glands (EGF; epidermal growth factor), thyroid gland $\left(\mathrm{T}_{3}\right.$, triiodthyronine) and adrenal glands (norepinephrine). These comitogens help initiate the recovery of the liver $(7,8,30,56)$.

\section{Proliferative phase}

Proliferative phase is characterised by mitotic waves of hepatic cells. The well obvious marker of the cell cycle progression is the rate of DNA synthesis observed to appear in a coordinated fashion in individual liver cell subpopulations. Hepatocytes reach the S phase first, with the DNA synthesis beginning to rise 12 hours after the $\mathrm{PH}$ and peaking at about 24 hours after the operation. The $\mathrm{S}$ phase in the nonparenchymal cells occurs later; at 48 hours for Kupffer and biliary cells and around 96 hours for endothelial cells $(12,56)$. After an insult causing necrosis or apoptosis of hepatocytes, the course of the cell priming is similar as after the $\mathrm{PH}$, but the replicative waves are less coordinated.

Functional heterogeneity of hepatocytes applies also to the onset of DNA synthesis within the liver acini, starting around the portal vein (zone I) and gradually proceeding towards the central vein (zone III).
During the proliferative phase almost all of the hepatocytes undergo mitosis. This percentage is approximately $95 \%$ in young rats and decreases to about $70 \%$ in old animals $(3,46)$. The mechanism of replicative senescence of the hepatocytes is not clarified so far. In humans there are less observations of such kind available, but in liver transplantation grafts from younger donors generally carry better outcome (67).

Not all the hepatocytes that passed the S phase finally replicate. The proportion of binucleate cells within the liver increases, and some hepatocytes become polyploid but undivided. The first mitotic wave concerning the vast majority of parenchymal cells is followed by a second one, about 48 hours after $\mathrm{PH}$, involving smaller percentage of hepatocytes. In total there is about 1.6 cycles of replication in all cells to fully restore the liver (56).

\section{Termination phase}

Cessation of the regenerative response is the least elucidated phase of the process. It is still not clear whether it is onset of inhibitory agents or withdrawal of stimulatory substances that finally stops regeneration. The interplay among the liver cell subpopulations and probable participation of the recovered extracellular matrix complicate revealing the mechanisms of observed precise liver size regulation. Nonparenchymal cells may mediate the inhibition of regrowth during structural reorganisation of the liver which comes after the volume regain is finished. Reappearing extracellular matrix may play an important role by renewed binding of pro-HGF (35).

Mechanisms that link the replicative activity of hepatocytes in the regenerating liver with body functional demands, have been sought and mammalian target of rapamycin (mTOR) and its downstream effectors belong to proposed candidates (11).

Factors with known inhibitory effects on hepatocyte proliferation in cultures such as TGF- $\beta 1$ (in vivo normally synthesized by Ito cells) have been subject of research. Some observations suggest that disappearance of (detectable) tissue TGF- $\beta 1$ from periportal to pericentral region of lobule enables progression of hepatocyte mitotic wave in the same direction at the onset of regeneration. TGF- $\beta 1$ released in the plasma shortly after $\mathrm{PH}$ is probably inactivated by binding to $\alpha 2$ macroglobulin. Hepatocytes themselves are transiently resistant to mito-inhibitory effects of TGF- $\beta 1$ during the proliferative phase. After this refractory period, TGF- $\beta 1$ could play a role in ending the regeneration, however in transgenic mice overexpressing TGF- $\beta 1$ regeneration is slowed down but it finally completes $(5,37)$. Related TGF $\beta$ family members, such as activin, act similarly.

Several negative feedback loop interactions related to priming phase stimuli were recognised. To name some of these: plasminogen activator inhibitor (PAI) induced by IL-6, blocks the HGF action by preventing the cleavage of 
pro-HGF into an active HGF. Suppressor of cytokine signalling-3 (SOCS3) upregulated downstream to IL-6, causes downregulation of phosphorylated signal transducer and activator of transcription 3 (STAT3) ultimately terminating the original IL-6 signal (56).

Apoptosis, as a possible mechanism correcting the resultant size of the liver was studied in normal and IL- $6 \%$ mice, by Sakamoto et al (1999). This work suggested greater role of apoptosis in normal than in IL-6 deficient liver in eliminating the superfluous hepatocytes generated by regeneration.

\section{Molecular biology methods to study mechanisms of the liver regeneration}

Given the long history of research interest in the liver regeneration, it is not surprising, that it has been studied by molecular biology methods as well. Early works, in the 1980 's, assessed the presence and relative abundance of the specific mRNAs by autoradiography measurements following membrane-based hybridisation techniques like Northern blot and Dot blot $(21,29,58)$. These approaches were eventually complemented by histochemistry and cytogenetic methods (36). These works mostly dealt with several genes of interest focusing on narrowly specified aspects of hepatocyte growth. Experiments by Taub and co-workers outstand by the number of genes analysed and the time intervals studied (18).

Experiments using the genetically engineered mice strains gained wider use in 1990's. The ability to permanently or transiently overexpress or suppress (knock out) a gene of choice has enabled much progress in studying the involvement of individual factors or whole transcription pathways in the process $(2,13)$.

Advent of microarray platforms, introduced in 1995, allowed for wider scope of gene expression analyses. Simultaneous gene expression analyses of thousands of genes raised a new challenge. It is now demanding to sort out genes truly related to the observed functional or morphological changes among many detected by high throughput microarray experiments. Usually time course of expression alterations after the intervention is used as a criterion for creating clusters, subgroups of genes with similar expres- sion patterns, which is based on assumption that common activation or suppression indicates functional relationships among transcripts. Much database searching necessarily follows when interpreting the findings $(15,39,59,64)$. Extensive use of public data repositories and bioinformatic platforms fosters their rapid development.

Real time PCR gene expression analyses usually complement high throughput methods. Either as a confirmative approach for selected genes or as a preliminary method for more precise focusing of laborious and expensive advanced techniques. Moreover the real time PCR provides wider linear dynamic range of transcript quantitation and thus refines the results. Work by Cimica et al. (2007), who used serial analysis of gene expression (SAGE) for one post partial hepatectomy interval based on previous real time PCR and immunostaining results, is a recent example of such combination of methods.

Interesting novel approach was used by Juskeviciute et al. (2008), who were able to identify previously unknown transcription factors participating in liver regeneration, thanks to bioinformatic analysis of shared transcription factor binding sites in the clustered microarray data.

\section{Interpreting recent microarray data}

Majority of so far published papers is focused on early changes after the liver insult, based on the notion, that the reactivation from quiescence and subsequent entry into the $\mathrm{S}$ phase of the cell cycle is the most exceptional feature of liver regeneration model. Propagation of the proliferative response seems to follow the same principles as seen in other extrahepatic cells or tissues, making later phases of regeneration less scientifically attractive. This general fact applies to microarray-based analyses as well.

As seen in Tab. 1, summarising several features of seven recently published studies using microarrays, the sample acquisition is usually denser in shorter intervals and becomes notably looser after 24 hours after the resection. Thus it would seem logical; that the molecular mechanisms underlying the first 12 or 24 hours of liver regeneration should be well described and understood in good agreement among the researchers. Unfortunately the situation is more complicated. Anyone trying to interpret the findings of large

Tab. 1: Recently published microarray-based works on liver regeneration and their sampling intervals.

\begin{tabular}{|c|c|c|c|c|c|c|c|c|c|c|c|c|c|c|c|c|c|c|c|c|c|c|c|c|c|}
\hline $\begin{array}{l}\text { First } \\
\text { author }\end{array}$ & PY & $\begin{array}{c}\text { Model } \\
\text { organism }\end{array}$ & & Post p & rtial & 1 hep & pate & ecto & my & sam & aplin & $\mathrm{ng}$ in & nter & vals & & & & & & & & & & & \\
\hline Mortensen & 2008 & pig & $1 \mathrm{~m}$ & $30 \mathrm{~m}$ & $90 \mathrm{~m}$ & & $3 \mathrm{~h}$ & $4 \mathrm{~h}$ & $6 \mathrm{~h}$ & & & & & & & & & & & & & & & & \\
\hline Fukuhara & 2003 & rat & & & & & & & $6 \mathrm{~h}$ & & $12 \mathrm{~h}$ & & $18 \mathrm{~h}$ & $24 \mathrm{~h}$ & & & & $48 \mathrm{~h}$ & & & & $72 \mathrm{~h}$ & & & 168 \\
\hline Togo & 2004 & mouse & & 60 & & & $3 \mathrm{~h}$ & & $6 \mathrm{~h}$ & & $12 \mathrm{~h}$ & & & $24 \mathrm{~h}$ & & & & & & & & & & & \\
\hline $\mathrm{Xu}$ & 2005 & rat & & & & $2 \mathrm{~h}$ & & $4 \mathrm{~h}$ & & $8 \mathrm{~h}$ & $12 \mathrm{~h}$ & $16 \mathrm{~h}$ & & $24 \mathrm{~h}$ & & $36 \mathrm{~h}$ & & $48 \mathrm{~h}$ & & & & \begin{tabular}{|l|l|}
$72 \mathrm{~h}$ & 96 \\
\end{tabular} & $96 \mathrm{~h}$ & & $144 \mathrm{~h}$ \\
\hline Shao & 2007 & rat & & \begin{tabular}{l|l|}
$30 \mathrm{~m}$ & 60 \\
\end{tabular} & & $2 \mathrm{~h}$ & & $4 \mathrm{~h}$ & $6 \mathrm{~h}$ & $8 \mathrm{~h}$ & $12 \mathrm{~h}$ & & & $24 \mathrm{~h}$ & & $36 \mathrm{~h}$ & & & $54 \mathrm{~h}$ & & $66 \mathrm{~h} / 72$ & $72 \mathrm{~h}$ & & $120 \mathrm{hl}$ & $144 \mathrm{~h} / 168 \mathrm{~h}$ \\
\hline Yokoya & 2004 & rat & & 60 & & & & & $6 \mathrm{~h}$ & & & & & $24 \mathrm{~h}$ & & & & $48 \mathrm{~h}$ & & & & & & & $168 \mathrm{~h}$ \\
\hline $\mathrm{Xu}$ & 2007 & rat & & $30 \mathrm{~m} / 60$ & & $2 \mathrm{~h}$ & & $4 \mathrm{~h}$ & $6 \mathrm{~h}$ & $8 \mathrm{~h}$ & $12 \mathrm{~h}$ & $16 \mathrm{~h}$ & $18 \mathrm{~h}$ & \begin{tabular}{l|l|l}
$24 \mathrm{~h}$ & 3 \\
\end{tabular} & \begin{tabular}{ll|l}
$30 \mathrm{~h}$ & 3 \\
\end{tabular} & \begin{tabular}{l|l|l}
$36 \mathrm{~h}$ & 4 \\
\end{tabular} & \begin{tabular}{l|l}
$42 \mathrm{~h}$ & 4 \\
\end{tabular} & \begin{tabular}{|l|l|}
$48 \mathrm{~h}$ & 5 \\
\end{tabular} & \begin{tabular}{|l|l|}
$54 \mathrm{~h}$ & 6 \\
\end{tabular} & $60 \mathrm{~h} \mid 6$ & $66 \mathrm{~h} / 72$ & \begin{tabular}{|l|l|}
$72 \mathrm{~h}$ & 9 \\
\end{tabular} & $96 \mathrm{~h} 12$ & $120 \mathrm{~h} / 1$ & $144 \mathrm{~h} \mid 168$ \\
\hline
\end{tabular}

$\mathrm{PY}=$ year of publication; $\mathrm{m}=$ minute $(\mathrm{s}) ; \mathrm{h}=$ hours $(\mathrm{s})$ 
Tab. 2: Differentially expressed genes common to at least two of the three compared microarray-based studies recently published on liver regeneration after partial hepatectomy in rodents.

\begin{tabular}{|l|c|c|}
\hline \multirow{2}{*}{ Gene name and its alternatives (including symbols)* } & Published in article \\
& - Ref. No. \\
\cline { 2 - 3 } & 64 & 47 \\
\hline $\begin{array}{l}\text { Cytochrome P450, family 7, subfamily a, polypeptide 1, Cyp 7a1, P-450 cholesterol } \\
\text { 7-alpha-hydroxylase, Cholesterol 7-alpha-monooxygenase }\end{array}$ & $\mathrm{X}$ \\
\hline Connective tissue growth factor precursor (Connective tissue growth-related protein). Ctgf & $\mathrm{X}$ \\
\hline $\begin{array}{l}\text { Dual specificity protein phosphatase 1 (EC 3.1.3.48) (EC 3.1.3.16) (MAP kinase phosphatase 1) } \\
\text { (MKP-1) (Protein-tyrosine phosphatase CL100) (Protein-tyrosine phosphatase non-receptor } \\
\text { type 16). }\end{array}$ & $\mathrm{X}$ & $\mathrm{X}$ \\
\hline $\begin{array}{l}\text { Early growth response factor 1 (Egr1) (KROX-24 PROTEIN) (ZIF268) (NERVE GROWTH } \\
\text { FACTOR-INDUCED PROTEIN A) (NGFI-A) }\end{array}$ & $\mathrm{X}$ \\
\hline $\begin{array}{l}\text { Plasminogen activator inhibitor 1 precursor (PAI-1) (Endothelial plasminogen activator inhibitor) } \\
\text { (PAI) Serine protease inhibitor 1(Serpin 1) (Serpine1) }\end{array}$ & $\mathrm{X}$ & $\mathrm{X}$ \\
\hline Cytochrome P450 15-beta (Cyp2c12) & $\mathrm{X}$ \\
\hline Alpha-2-macroglobulin precursor (Alpha-2-M). A2m & $\mathrm{X}$ \\
\hline $\begin{array}{l}\text { Bile acid CoA:amino acid N-acyltransferase (EC 2.3.1.65) (BAT) (BACAT) (Glycine } \\
\text { N-choloyltransferase) (Kan-1) (Long-chain fatty-acyl-CoA hydrolase) (EC 3.1.2.2). (Baat) }\end{array}$ & $\mathrm{X}$ & $\mathrm{X}$ \\
\hline (Hepatic) Flavin-containing monooxygenase 1 (Fmo1) & $\mathrm{X}$ \\
\hline
\end{tabular}

*found in Ensembl Genome Browser and Entrez Gene databases (23, 33)

scale gene expression studies, as these listed, soon encounters several principal difficulties.

Firstly, the overlap between the results of microarraybased studies is commonly much smaller than would be expected. As noted by van Bakel and Holstege (2008), comparing independently obtained lists of differentially expressed genes from several experiments on the same topic may end up in very limited number of shared matches. In the model example shown in their work, three gene lists containing 115, 160 and 250 genes respectively, only 15 genes were common to all the lists. We made a similar experience comparing three published gene lists from references 63,47 and 66 and yielding mere nine genes common to at least two of the three works (see Tab. 2). This is caused most probably by varied microarray platforms and methodology of working with the data, e.g. different cut off values for fold change in gene expression level.

Interpreting effort is moreover complicated by nonuniform way of presenting results, regarding the gene names, symbols or database annotations. Not having the raw data, reader of the papers is dependent on some of the comprehensive databases such as Entrez Gene (33), Ensembl Genome Browser (23) or Rat Genome Database (RGD) (60) in finding the missing descriptors to decide whether the gene results from different studies do or do not overlap. The authors list their gene results with various level of exactness, not always using unambiguous names or codes like Entrez Gene ID, Ensembl Gene ID or RGD Gene ID.

The most desired information from large scale studies is not about several individual genes confirmed among thousands under investigation, but about functional classes or even better cellular pathways involved in the particular steps of liver regeneration. Time course experiments also should unravel the temporal pattern of their involvement. Are we able to answer these questions then? Well, it is not rare that authors group their explored differentially expressed genes into categories based on functional relationships (e.g. 57), but the problem again occurs when trying to classify genes from more studies together. Still, it is the uncertainty in describing the genes, what complicates this task. Fortunately, sophisticated and moreover user-friendly tools were developed to ease such an effort. What we strive to get is the functional classification of genes and there are bioinformatic instruments available to do that. One of the possible ones is DAVID database accessible free of charge via the internet (22; this work also lists some alternative tools for functional annotation and principles they utilize in its Supplementary Data 1).

With help of DAVID database we searched through gene lists derived from the seven papers listed in Tab. 1. Doing the same comparison among the gene lists „manually“ without such an aid is obviously laborious and thus discouraging.

To avoid that, we wanted to begin the work with well characterised background. This we derived from Gene Ontology database (57). We chose the biological process GO:0006953 acute-phase response, surely involved in early phases of liver regeneration after surgical resection. For Rattus norvegicus species there were 23 gene products annotated under this term in GO database release 2009-09-24. We consequently used these genes as a user defined Gene List for upload into the DAVID database. There, using the ID conversion tool, we were able to obtain unambiguous descriptors for all the 23 genes. We decided for conversion into following four categories: RGD ID, GENE SYMBOL, ENTREZ GENE ID and UNIGENE. Results of the conversion are summarized in the Tab. 3 . 
Tab. 3: Genes involved in acute phase response and their coverage in the seven compared microarray-based studies.

\begin{tabular}{|c|c|c|c|c|c|c|c|c|c|c|c|}
\hline & & & & Ref No. & 64 & 47 & 66 & 39 & 59 & 15 & 65 \\
\hline Gene Name & RGD ID & \begin{tabular}{|l|l} 
GENE \\
SYMBOL
\end{tabular} & \begin{tabular}{l|} 
ENTREZ \\
GENE ID
\end{tabular} & UNIGENE & & & & & & & \\
\hline $\begin{array}{l}\text { BILE ACID-COENZYME A: AMINO ACID } \\
\text { N-ACYLTRANSFERASE }\end{array}$ & 2190 & BAAT & 29725 & RN.11129 & & $\mathrm{X}$ & $\mathrm{X}$ & & & $\mathrm{X}$ & \\
\hline $\begin{array}{l}\text { LIPOPOLYSACCHARIDE BINDING } \\
\text { PROTEIN }\end{array}$ & 61865 & LBP & 29469 & RN.48863 & & & & & & & \\
\hline $\begin{array}{l}\text { TRANSIENT RECEPTOR POTENTIAL } \\
\text { CATION CHANNEL, SUBFAMILY V, } \\
\text { MEMBER } 1\end{array}$ & 628841 & TRPV1 & 83810 & RN.3073 & & & & & & & \\
\hline TRANSFERRIN & 3845 & TF & 24825 & RN.91296 & & & & & & & \\
\hline ENDOTHELIN RECEPTOR TYPE B & 2536 & EDNRB & 50672 & RN.11412 & & & & & & & \\
\hline $\begin{array}{l}\text { PROSTAGLANDIN E RECEPTOR } 3 \\
\text { (SUBTYPE EP3) }\end{array}$ & 3435 & PTGER3 & 24929 & RN.10361 & & $\mathrm{X}$ & & & & & \\
\hline INTERLEUKIN 1 BETA & 2891 & IL1B & 24494 & RN.9869 & & & & & & & \\
\hline $\begin{array}{l}\text { SIGNAL TRANSDUCER AND ACTIVATOR } \\
\text { OF TRANSCRIPTION } 3\end{array}$ & 3772 & STAT3 & 25125 & RN.10247 & & & $\mathrm{X}$ & & & & \\
\hline ALPHA-2-MACROGLOBULIN & 2004 & A2M & 24153 & RN.780 & $\mathrm{X}$ & $\mathrm{X}$ & $\mathrm{X}$ & & & & $\mathrm{X}$ \\
\hline TUBEROUS SCLEROSIS 2 & 3908 & TSC2 & 24855 & RN.5875 & & & & & & & \\
\hline $\begin{array}{l}\text { PHOSPHOLIPASE A2, GROUP IVA } \\
\text { (CYTOSOLIC, CALCIUM-DEPENDENT) }\end{array}$ & 67366 & PLA2G4A & 24653 & RN.10162 & & & & & & & \\
\hline TRANSFERRIN RECEPTOR & 70488 & TFRC & 64678 & RN.98672 & & & & & & & \\
\hline $\begin{array}{l}\text { SIMILAR TO SINGLE IG IL-1 RECEPTOR } \\
\text { RELATED PROTEIN }\end{array}$ & 1306732 & SIGIRR & 309106 & RN.16525 & & & & & & & \\
\hline INSULIN 2 & 2916 & INS2 & 24506 & RN.989 & & & & & & & \\
\hline $\begin{array}{l}\text { CCAAT/ENHANCER BINDING PROTEIN } \\
\text { (C/EBP), ALPHA }\end{array}$ & 2326 & CEBPA & 24252 & RN.22163 & & & & & & & \\
\hline EPH RECEPTOR A3 & 68389 & EPHA3 & 29210 & RN.10713 & & & & & & & \\
\hline ARGININOSUCCINATE SYNTHETASE & 2163 & ASS & 25698 & RN.5078 & & & & & & & \\
\hline CHEMOKINE (C-C) RECEPTOR 5 & 620596 & CCR5 & 117029 & RN.10736 & & & & & & & \\
\hline $\begin{array}{l}\text { INTERLEUKIN } 1 \text { RECEPTOR } \\
\text { ANTAGONIST }\end{array}$ & 621159 & IL1RN & 60582 & RN.85806 & & $\mathrm{X}$ & & & & & \\
\hline $\begin{array}{l}\text { MACROPHAGE INFLAMMATORY } \\
\text { PROTEIN-1 ALPHA RECEPTOR GENE }\end{array}$ & 708446 & CCR1 & 57301 & RN.34673 & & & & & & & \\
\hline ALPHA-2-HS-GLYCOPROTEIN & 2075 & AHSG & 25373 & RN.32083 & & & & & & & \\
\hline $\begin{array}{l}\text { SIGNAL TRANSDUCER AND ACTIVATOR } \\
\text { OF TRANSCRIPTION 5B }\end{array}$ & 3774 & STAT5B & 25126 & RN.54486 & & & & & & & \\
\hline CHEMOKINE (C-C MOTIF) LIGAND 5 & 69069 & CCL5 & 81780 & RN.8019 & & & & & & & \\
\hline
\end{tabular}

Thanks to this prerequisite, searching for the genes involved in the acute phase response among all the seven large scale studies became significantly more efficient. Resultant findings are also in the Tab. 3. Although there are again only scarce matches to the gene products we were looking for, confirming small overlap between independent papers, we want to emphasize the benefit of such interpreting procedure. It lies mainly in removing uncertainty from the gene specifications and thus allowing comparison of the results originally presented using different ways, e.g. only gene names or its symbols vs. giving the database descriptors which unfortunately may turn obsolete from the time of publication. The latter being frequent impediment given the perpetually ongoing refinements and updates to the internet-based genomic databases. Finally, the similar approach may be used for any of the Gene Ontology functional categories, allowing anyone interested to focus on the field of their study.

\section{Conclusion}

This article deals with liver regeneration, the unique ability of the liver to recover from serious damages. The article describes significance of this interdisciplinary study topic and summarizes current knowledge in the field. Particular attention is paid to molecular biology methods utilized in liver regeneration studies. Finally, authors provide a discussion of possible obstacles in interpreting the recent findings from microarray-based studies and propose their way of circumventing them as a solution for others experiencing similar difficulties. 


\section{Acknowledgement}

The work described in this article is supported by $\mathrm{Mi}$ nistry of Education grant MSM 0021620820, Charles University Grant Agency grant No. 9945/2009(94509) and Internal grant of the Charles University in Prague, Faculty of Medicine in Hradec Králové with support from ROCHE, No. 84024.

\section{List of abbreviations}

AP-1, activator protein 1 (= c-jun); CEBP, CCAAT/enhancer binding protein; EGF, epidermal growth factor; $\mathrm{HGF}$, hepatocyte growth factor; NFKB, nuclear factor of kappa light polypeptide gene enhancer in B-cells; PAI, plasminogen activator inhibitor; SOCS3, suppressor of cytokine signalling-3; STAT3, signal transducer and activator of transcription 3; TGF, transforming growth factor

\section{References}

1. Beavers KL, Sandler RS, Shresta R. Donor morbidity assosciated with right lobectomy for living donor liver transplantation to adult recipients: a systematic review. Liver Transplantation 2002;8:110-17

2. Braun KM, Sandgren EP. Liver disease and compensatory growth: unexpected lessons from genetically altered mice. Int J Dev Biol 1998;42:935-42.

3. Bucher NL. Regeneration of mammalian liver. Int Rev Cytol 1963;15:245-300.

4. Cimica V, Batusic D, Haralanova-Ilieva B, et al. Serial analysis of gene expression (SAGE) in rat liver regeneration. Biochem Biophys Res Commun 2007;360:545-52.

5. Court FG, Wemyss-Holden SA, Dennison AR, Maddern GJ. The mystery of liver regeneration. British Journal of Surgery 2002;89:1089-95.

6. Cressman DE, Greenbaum LE, DeAngelis RA, et al. Liver failure and defective hepatocyte regeneration in interleukin-6-deficient mice. Science 1996;274:1379-83.

7. Červinková Z, Šimek J, Trojovská V. Effect of triiodothyronine or etiroxate on DNA synthesis in intact and regenerating liver. Physiol bohemoslov 1984; 33(6):501-6

8. Červinková Z, Šimek J. Effect of propylthiouracil on liver regeneration in rats after partial hepatectomy. Physiol Res 1992;41:141-6.

9. Erhard J, Lange R, Giebler R, Rauen U, de Groot H, Eigler FW. Arterialization of the portal vein in orthotopic and auxiliary liver transplantation. A report of three cases. Transplantation 1995;60:877-90.

10. Etienne PL, Baffet G, Desvergne B, Boisnard-Rissel M, Glaise D, GuguenGuillouzo C. Transient expression of c-fos and constant expression of c-myc in freshly isolated and cultured normal adult rat hepatocytes. Oncogene Research 1988:3:255-62.

11. Fausto N, Campbell JS, Riehle KJ. Liver regeneration. Hepatology 2006;43: S45-S53.

12. Fausto N, Riehle KJ. Mechanisms of liver regeneration and their clinical implications. J Hepatobiliary Pancreat Surg 2005;12:181-9.

13. Fausto N. Lessons from genetically engineered animal models. V. Knocking out genes to study liver regeneration: present and future. Am J Physiol 1999; 277(5):G917-21

14. Fausto N. Liver regeneration. Journal of Hepatology 2000;32(suppl 1):19-31.

15. Fukuhara Y, Hirasawa A, Li XK, et al. Gene expression profile in the regenerating rat liver after partial hepatectomy. J Hepatol 2003;38:784-92.

16. Gaub J, Iversen J. Rat liver regeneration after $90 \%$ partial hepatectomy. Hepatology 1984;4:902-4

17. Golubovskaya VM, Presnell SC, Hooth MJ, Smith GJ, Kaufmann WK. Expression of telomerase in normal and malignant rat hepatic epithelia. Oncogene 1997; 15(10):1233-40.

18. Haber BA, Mohn KL, Diamond RH, Taub R. Induction patterns of 70 genes during nine days after hepatectomy define the temporal course of liver regeneration. J Clin Invest 1993;91:1319-26.

19. Higgins GM, Anderson RM. Experimental pathology of the liver. I. Restoration of the liver of the white rat following partial surgical removal. Arch. Pathol. 1931; 12:186-202.

20. Hockings PD, Roberts T, Campbell SP, et al. Longitudinal Magnetic Resonance Imaging Quantitation of Rat Liver Regeneration After Partial Hepatectomy. Toxicologic Pathology 2002;30(5):606-610.

21. Hsieh LL, Peraino C, Weinstein IB. Expression of endogenous retrovirus-like sequences and cellular oncogenes during phenobarbital treatment and regeneration in rat liver. Cancer Res 1988;48:265-9.
22. Huang DW, Sherman BT, Lempicki RA. Systematic and integrative analysis of large gene lists using DAVID Bioinformatics Resources. Nature Protocols 2009;4(1):44-57.

23. Hubbard TJP, Aken BL, Ayling S, et al. Ensembl 2009. Nucleic Acids Research [online] 2009;37:D690-D697.

24. Humar A, Kosari K, Sielaff TD, et al. Liver regeneration after adult living donor and deceased donor split-liver transplants. Liver Transpl 2004;10:374-8.

25. Ikeda T, Sawada N, Fujinaga K, Minase T, Mori M. c-H-ras gene is expressed at the G1 phase in primary cultures of hepatocytes. Exp. Cell Res. 1989;185:292-6. 26. Jansen PL, Chamuleau RA, van Leeuwen DJ, Schipper HG, Busemann-Sokole E, van der Heyde MN. Liver regeneration and restoration of liver function after partial hepatectomy in patients with liver tumors. Scand J Gastroenterol 1990;25(2): tial hep 112 .

27. Juskeviciute E, Vadigepalli R, Hoek JB. Temporal and functional profile of the transcriptional regulatory network in the early regenerative response to partial hepatectomy in the rat. BMC Genomics 2008;9:527.

28. Krejsek J, Kopecký O. Klinická imunologie. $1^{\text {st }}$ ed. Hradec Králové: NUCLEUS HK, 2004:968

29. Kruijer W, Skelly H, Botteri F, et al. Proto-oncogene expression in regenerating liver is simulated in cultures of primary adult rat hepatocytes. J Biol Chem 1986; 261:7929-33.

30. Křiváková P. Hepatocyty jako modelový systém pro studium poruch energetického metabolismu (Dissertation). [s.1.]: Univerzita Karlova v Praze, Lékařská fakulta v Hradci Králové, 2006. 135pp.

31. Liu ML, Mars WM, Zarnegar R, Michalopoulos GK. Collagenase pretreatment and the mitogenic effects of hepatocyte growth factor and transforming growth factor-alpha in adult rat liver. Hepatology 1994;19:1521-7.

32. Loyer P, Cariou S, Glaise D, Bilodeau M, Baffet G, Guguen-Guillouzo C. Growth factor dependence of progression through $\mathrm{G} 1$ and $\mathrm{S}$ phases of adult rat hepatocytes in vitro. Evidence of a mitogen restriction point in mid-late G1. J Biol Chem 1996;271(19):11484-92.

33. Maglott D, Ostell J, Pruitt KD, Tatusova T. Entrez Gene: gene-centered information at NCBI. Nucleic Acids Research [online] 2005;33:D54-D58.

34. Manzarbeitia C, ed. Practical Manual of Abdominal Organ Transplantation. New York: Kluwer Academic Publishers, 2002.

35. Mastellos D, Papadimitriou JC, Franchini S, Tsonis PA. Lambris JD. A novel role of complement: mice deficient in the fifth component of complement (C5) exhibit impaired liver regeneration. J Immunol 2001;166:2479-86.

36. Michalopoulos G, Cianciulli HD, Novotny AR, Kligerman AD, Strom SC, Jirtle RL. Liver regeneration studies with rat hepatocytes in primary culture. Cancer Res 1982;42:4673-82.

37. Michalopoulos GK, DeFrances MC. Liver regeneration. Science 1997;276:60-6.

38. Michalopoulos GK. Liver Regeneration. Journal of Cellular Physiology 2007; 213:286-300.

39. Mortensen KE, Conley LN, Hedegaard J, et al.: Regenerative response in the pig liver remnant varies with the degree of resection and rise in portal pressure. Am J Physiol Gastrointest Liver Physiol 2008;294:G819-30.

40. Ogata A, Miyazaki M, Ohtawa S, Ohtsuka M, Nakajima N. Short-term effects of portal vein arterialization on hepatic protein synthesis and endotoxaemia after extended hepatectomy in dogs. Journal of Gastroenterology and Hepatology 1997; 12:633-8.

41. Overturf K, al-Dhalimy M, Ou CN, Finegold M, Grompe M. Serial transplantation reveals the stem-cell-like regenerative potential of adult mouse hepatocytes. American Journal of Pathology 1997;151:1273-80.

42. Ozeki Y, Umemoto T, Tateyama K, Katagiri Y, Katayama M, Sugiyama A. Partial portal arterialization for dearterialized liver after hepatectomy. British Journal of Surgery 1997;84:1011.

43. Palmes D, Spiegel H-U. Animal models of liver regeneration. Biomaterials 2004;25:1601-1611

44. Pomfret EA, Pomposelli JJ, Gordon FD, et al. Liver regeneration and surgica outcome in donors of right-lobe liver grafts. Transplantation 2003;76:5-10.

45. Sakamoto T, Liu Z, Murase N, et al. Mitosis and apoptosis in the liver of interleukin-6-deficient mice after partial hepatectomy. Hepatology 1999;29:403-11.

46. Sawada N. Hepatocytes from old rats retain responsiveness of c-myc expression to EGF in primary culture but do not enter S phase. Exp Cell Res 1989;181 $584-8$.

47. Shao HY, Zhao LF, Xu CS. Expression patterns and action analysis of genes associated with inflammatory responses during rat liver regeneration. World $\mathrm{J}$ Gastroenterol 2007;13(3):369-77.

48. Sherlock S, Dooley J. Nemoci jater a žlučových cest. $1^{\text {st }}$ Czech edition [Czech translation editor Petr Hủlek] Hradec Králové: Čermáková, 2004:703.

49. Starzl TE, Putnam CW, Groth CG, Corman JL, Taubman J. Alopecia, ascites, and incomplete regeneration after 85-90 per cent liver resection. American Journal of Surgery 1975;129:587-90.

50. Steer CJ. Liver regeneration. FASEB Journal 1995;9(14):1396-1400.

51. Stocker E, Wullstein HK, Brau G. Capacity of regeneration in liver epithelia of juvenile, repeated partially hepatectomized rats. Autoradiographic studies after continuous infusion of 3H-thymidine (author's transl). Virchows Archiv 1973; 14:93-103. 
52. Stolz DB, Mars WM, Petersen BE, Kim TH, Michalopoulos GK. Growth factor signal transduction immediately after two-thirds partial hepatectomy in the rat. Cancer Res 1999;59:3954-60.

53. Strey CW, Markiewski M, Mastellos D, et al. The proinflammatory mediator C3a and C5a are essential for liver regeneration. J Exp Med 2003;198:913-23.

54. Tarlá MR, Ramalho FS, Ramalho LNZ, et al. A molecular view of liver regeneration. Acta Cir Bras 2006;21(suppl 1):58-62. [serial on the Internet]. Available from URL: http://www.scielo.br/acb

55. Tarlá MR, Ramalho FS, Ramalho LNZ, et al. Cellular aspects of liver regeneration. Acta Cir Bras 2006;21(suppl 1):63-66. [serial on the Internet]. Available from URL: http://www.scielo.br/acb

56. Taub R. Liver regeneration: from myth to mechanism. Nature Reviews Molecular Cell Biology 2004;5:836-47.

57. The Gene Ontology Consortium. Gene ontology: tool for the unification of biology. Nature Genetics 2000;25(1):25-9.

58. Thompson NL, Mead JE, Braun L, Goyette M, Shank PR, Fausto N. Sequential protooncogene expression during rat liver regeneration. Cancer Res 1986;46: $3111-7$.

59. Togo S, Makino H, Kobayashi T, et al. Mechanism of liver regeneration after partial hepatectomy using mouse cDNA microarray. J Hepatol 2004:40:464-71.

60. Twigger SN, Shimoyama M, Bromberg S, Kwitek AE, Jacob HJ. RGD Team. The
Rat Genome Database, update 2007 - easing the path from disease to data and back again. Nucleic Acids Research [online] 2007;35:D658-D662.

61. van Bakel H, Holstege FCP. A Tutorial for DNA Microarray Expression Profiling. In: Zuk D, ed. Evaluating Techniques in Biochemical Research. Cambridge, MA: Cell Press, 2007:22-27.

62. Wagenaar GT, Chamuleau RA, Pool CW, et al. Distribution and activity of glutamine synthase and carbamoylphosphate synthase upon enlargement of the liver lobule by repeated partial hepatectomies. J Hepatol 1993;17(3):397-407.

63. Wege H, Müller A, Müller L, Petri S, Petersen J, Hillert C. Regeneration in pig livers by compensatory hyperplasia induces high levels of telomerase activity. Comparative Hepatology 2007;6:6.

64. Xu CS, Chang CF, Yuan JY, et al. Expressed genes in regenerating rat liver after partial hepatectomy. World J Gastroenterol 2005;11:2932-40.

65. Xu CS, Zhang SB, Chen XG, Rahman S. Correlation analysis of liver tumorassociated genes with liver regeneration. World J Gastroenterol 2007:13(24): 3323-32.

66. Yokoya F, Okutsu T. Gene panel participating in liver regeneration. European Patent Office Bulletin 2004/01

67. Yoshizumi T, Taketomi A, Uchiyama H, et al. Graft size, donor age, and patient status are the indicators of early graft function after living donor liver transplantation. Liver Transpl 2008;14:1007-13.

Received: 03/06/2009.

Accepted in revised form: 20/09/2009.

\section{Corresponding author:}

David Rychtrmoc, MD, Charles University in Prague, Faculty of Medicine in Hradec Králové, Department of Physiology, Šimkova 870, 50038 Hradec Králové 1, Czech Republic; e-mail: rychtrmocd@lfhk.cuni.cz 